\title{
Iron Transport in Mycobacterium smegmatis: The Location of Mycobactin by Electron Microscopy
}

\author{
By COLIN RATLEDGE, * PANKAJ V. PATEL + ANd JANICE MUNDY \\ Department of Biochemistry, University of Hull, Hull HU6 $7 R X, U . K$.
}

(Received 16 November 1981)

\begin{abstract}
Mycobactin, the lipid-soluble iron-binding compound of the mycobacteria, has been located using electron microscopy of whole cells stained with vanadate. It forms a discrete, discontinuous region close to, or even included in, the cytoplasmic membrane of Mycobacterium smegmatis. It does not occur throughout the whole thickness of the wall but is some distance within the envelope. Possible models for the accommodation of mycobactin are discussed. It is concluded from these observations that mycobactin may be acting either as a store of iron, or as an ionophore, or possibly fulfilling both roles.
\end{abstract}

\section{INTRODUCTION}

Mycobactin is a low molecular weight, lipid-soluble, ferric iron-binding compound found in all mycobacteria, save for Mycobacterium paratuberculosis and some strains of $M$. avium which require it as a growth factor (Snow, 1970). The amount of mycobactin produced varies from species to species but is always greatly increased by growth under iron-deficient conditions. In $M$. smegmatis, mycobactin can attain $10 \%$ of the cell dry weight (Ratledge \& Marshall, 1972); all of it is associated with the cell and none is found extracellularly. It has been thought to be involved in iron transport, since it rapidly takes up iron both as $\mathrm{Fe}$ (II), which is then rapidly oxidized to $\mathrm{Fe}$ (III), and as $\mathrm{Fe}$ (III) chelated to salicylic acid, the latter being produced mainly extracellularly by the mycobacteria (Ratledge \& Marshall, 1972; Ratledge et al., 1974). More recent studies, however, indicate that mycobactin may also act as a store when a large excess of iron is suddenly presented to the cells (McCready \& Ratledge, 1978, 1979).

We have attempted to locate mycobactin to help clarify its role in iron assimilation. In view of what was already known about mycobactin, we anticipated that it would be found within the cell envelope. The envelope of the mycobacteria contains much lipid and is extremely thick (estimates of up to $30 \mathrm{~nm}$ having been given; see Ratledge, 1976). It is predominantly a matrix of several different types of very long-chain lipids attached, via an arabinogalactan, to the peptidoglycan backbone of the wall which abuts a conventional cytoplasmic membrane (Minnikin, 1982). Further 'wall associated' lipids add to the lipophilicity and thickness of the wall (Lederer, 1971).

Conventional means of examining cell structures by electron microscopy of thin sections involve dehydration of the cell with ethanol or other solvents, but unfortunately both desferrimycobactin and ferrimycobactin are readily extracted from mycobacteria with ethanol. We have therefore developed a means of selectively staining mycobactin so that it is visible in whole bacteria, thereby avoiding the use of dehydrating solvents. Our results show, for the first time, the precise intracellular location of a microbial siderophore, although Müller \& Winkelmann $(1980,1981)$ have recently shown that coprogen, the siderophore from Neurospora crassa, binds very strongly and apparently to specific binding sites on isolated

+ Present address: Department of Microbiology, University of Birmingham, Birmingham B15 2TT. 
plasma membranes of $N$. crassa. Coprogen, though, like most other microbial siderophores, fulfils both an extracellular iron-scavenging role as well as being the means of translocating iron into the cell. Consequently, the applicability of our findings to the location of other microbial siderophores is probably very limited.

\section{METHODS}

Organism and growth. Mycobacterium smegmatis NCTC 8578 was grown in shaken cultures at $37^{\circ} \mathrm{C}$ on a glycerol/asparagine medium that had been pre-treated to remove iron (Ratledge \& Hall, 1971) and then supplemented with $0.05 \mu \mathrm{g} \mathrm{Fe} \mathrm{ml} l^{-1}$ for iron-deficient growth and with $2.0 \mu \mathrm{g} \mathrm{Fe} \mathrm{ml} l^{-1}$ for iron-sufficient growth.

Whole-cell electron microscopy. As thin sections of cells could not be prepared without loss of mycobactin (see Results), and as iron itself proved to be too non-specific to stain mycobactin selectively, the following procedure using metavanadate was devised. A $4 \mathrm{~d}$ culture of $M$. smegmatis was chilled to $4{ }^{\circ} \mathrm{C}$, and made $0 \cdot 1 \%$ (w/v) with respect to ammonium metavanadate. After shaking at $4{ }^{\circ} \mathrm{C}$ for $10 \mathrm{~min}$, a drop of the culture was placed on a collodion-coated copper grid and left for $30 \mathrm{~s}$ to allow bacteria to settle. The excess fluid was taken off with filter paper. The grids were quickly dried in the air at room temperature and then immediately examined in an electron microscope. When iron was tried as a selective stain, it was presented to the cells as a freshly prepared solution of $\mathrm{FeCl}_{3}$ in $0.1 \mathrm{M}-\mathrm{HCl}$ to give a $0.006 \%$ solution and the above procedure was repeated.

Identification of vanadyl mycobactin formed in situ. A $100 \mathrm{ml}$ culture to which ammonium metavanadate solution, $\mathrm{pH} \mathrm{7.0,} \mathrm{had} \mathrm{been} \mathrm{added} \mathrm{(as} \mathrm{above)} \mathrm{was} \mathrm{centrifuged} \mathrm{at} 8000 \mathrm{~g}$ for $20 \mathrm{~min}$ at $4{ }^{\circ} \mathrm{C}$. The cell pellet was washed three times in minimal medium at $4{ }^{\circ} \mathrm{C}$ and the cells were then extracted with $100 \mathrm{ml}$ ethanol for $24 \mathrm{~h}$. The suspension was filtered through filter paper (Whatman no. 1) and the cells were dried at $37^{\circ} \mathrm{C}$ under vacuum to a constant weight. The dried cells were digested by boiling for $20 \mathrm{~min}$ in conc. $\mathrm{H}_{2} \mathrm{SO}_{4} / 60 \%(\mathrm{w} / \mathrm{w}) \mathrm{HClO}_{4}(3: 2, \mathrm{v} / \mathrm{v})$, and the resulting solution was made to $50 \mathrm{ml}$ with distilled water, filtered and made up to $100 \mathrm{ml}$ with $0.5 \mathrm{M}-\mathrm{H}_{2} \mathrm{SO}_{4}$. The content of vanadium was determined by atomic absorption spectrophotometry (see below). To the ethanol extract was added chloroform ( 2 vol.) and distilled water ( 2 vol.). The chloroform layer was removed and washed twice with $0.9 \%(\mathrm{w} / \mathrm{v}) \mathrm{NaCl}$, dried over anhydrous $\mathrm{MgSO}_{4}$ and evaporated to dryness, and the residue was dissolved in methanol. After determining the u.v. and visible spectra of the solution, a sample was removed to determine its content of vanadium by atomic absorption spectrophotometry and a further sample was chromatographed together with an authentic sample of vanadyl mycobactin on a thin $(0.25 \mathrm{~mm})$ layer of silica gel $\mathrm{G}$ using petroleum ether (b.p. $\left.40-60^{\circ} \mathrm{C}\right)$ /butanol/ethyl acetate $(2: 3: 3$, by vol.). Authentic vanadyl mycobactin was prepared from desferrimycobactin, purified from $M$. smegmatis. Desferrimycobactin in ethanolic solution was mixed with ammonium metavanadate and the excess metavanadate was removed by the same procedure as used for removing excess iron from a preparation of ferrimycobactin (see below). The chloroform solution of vanadyl mycobactin was evaporated and the residue was dissolved in ethanol.

Determination of mycobactin in cells and other samples. Mycobactin was extracted from cells with ethanol, converted to its ferric complex and estimated by its absorption at $450 \mathrm{~nm}\left(A_{450}^{1 \%}=42 \cdot 8\right)$ (Snow, 1970). For its determination in various solvents, an excess of $\mathrm{FeCl}_{3}$ in ethanol (the concentration was not important) was added and the ferrimycobactin was extracted with chloroform. After removing the excess iron by washing with water, the chloroform solution was evaporated, the residue was dissolved in methanol and its absorbance was determined.

Atomic absorption spectrophotometry. Vanadium and iron were estimated in various solutions by atomic absorption spectrophotometry. Three readings for each sample were obtained. Appropriate corrections were made for the background reading.

\section{RES ULTS}

Mycobacterium smegmatis was grown in iron-deficient medium so that it contained 4-8\% (w/w) mycobactin. Although no mycobactin was lost during fixation of the cells with either $4 \%(\mathrm{w} / \mathrm{v})$ glutaraldehyde, $1 \%(\mathrm{w} / \mathrm{v}) \mathrm{OsO}_{4}, \mathrm{OsO}_{4} / \mathrm{K}_{2} \mathrm{Cr}_{2} \mathrm{O}_{7}$ or with dual fixation using $2.5 \%$ $(\mathrm{w} / \mathrm{v})$ glutaraldehyde followed by $1 \%(\mathrm{w} / \mathrm{v}) \mathrm{OsO}_{4}$ prior to preparing thin sections (see Hayat, 1970), none of these procedures prevented almost total loss of mycobactin during subsequent dehydration with increasing concentrations of acetone or ethanol solutions in water $(30-100 \%, v / v)$. (Mycobactin was estimated in the wash solutions, and in the cells, by extraction into ethanol and measurement of $A_{450}^{1 \%}$; see Methods.) Losses of mycobactin were still substantial (34-58\%) even when $0.5 \%(\mathrm{w} / \mathrm{v})$ uranyl acetate was used as a post-fixative following treatment with $\mathrm{OsO}_{4}$ (Ryter et al., 1958) - a procedure which some other workers 
have found satisfactory for preserving phospholipids in thin sections of biological materials (Silva et al., 1971; Biava \& Shelley, 1968). The same result was obtained when the desferrimycobactin within the cells was first converted to ferrimycobactin by incubating whole cells with ferrisalicylate in $0.1 \mathrm{M}$-Tris/ $\mathrm{HCl}$. In all subsequent studies, therefore, we used whole cells processed by negative-staining techniques to avoid the use of dehydrating solvent. However, when whole cells of $M$. smegmatis were incubated with $20 \mu \mathrm{g} \mathrm{Fe}$ (III) ml ${ }^{-1}$ for $3 \mathrm{~min}$ and then examined by electron microscopy, a considerable amount of non-specific binding of the iron to the cell surface was seen with cells grown in iron-deficient or iron-sufficient medium (not shown). Although only the iron-deficient cells turned pink, due to formation of ferrimycobactin, the lack of specificity of the iron as an electron microscopy stain indicated that a more selective stain was needed if we were to obtain unequivocal results concerning the location of mycobactin. Ammonium metavanadate was found to be such a stain. Snow (1969) has shown that metavanadate forms a stable vanadyl (VO) complex with mycobactin: the reaction of ammonium metavanadate $\left(\mathrm{NH}_{4} \mathrm{VO}_{3}\right)$ with desferrimycobactin $\left(\mathrm{DH}_{3}\right)$ to give vanadyl mycobactin can be represented as: $\mathrm{DH}_{3}+\mathrm{VO}_{3}^{-}+\mathrm{H}^{+} \rightleftharpoons \mathrm{DVO}+2 \mathrm{H}_{2} \mathrm{O}$.

\section{Formation of vanadyl mycobactin in situ in whole cells}

Ammonium metavanadate was added to cultures of $M$. smegmatis grown for $4 \mathrm{~d}$ in iron-deficient or iron-sufficient medium, and after $10 \mathrm{~min}$ the cells were washed and extracted with ethanol (see Methods). The extract from iron-deficient cells was orange, whereas that from iron-sufficient cells was colourless. The u.v. and visible spectrum of the former solution was identical to that of authentic vanadyl mycobactin S. Both authentic and extracted vanadyl mycobactin turned purple when brought to $\mathrm{pH} 0.5$ with $5 \mathrm{M}-\mathrm{HCl}$ (most other metal complexes with mycobactin dissociate at low $\mathrm{pH}$ values - Snow, 1969) and ran with identical $R_{F}$ values $(0.41)$ when subjected to thin-layer chromatography (see Methods). Elemental analysis of the cell debris after ethanol extraction showed that in iron-deficient cells there remained $0.21 \mathrm{mg}$ vanadium ( $\mathrm{g}$ cell dry $\mathrm{wt})^{-1}$ and in iron-sufficient cells there was $0.13 \mathrm{mg}$ $\mathrm{g}^{-1}$; this compared with $1.7 \mathrm{mg}$ vanadium $\mathrm{g}^{-1}$ extracted with ethanol from iron-deficient cells (none could be extracted from the iron-sufficient cells). It was concluded that the unextracted vanadium was attached to cell components common to both types of cells (e.g. polyphosphate granules, see Figs 1 to 3 ) and that the ethanol-soluble vanadium was vanadyl mycobactin.

Vanadate, besides being more specific than iron for detecting mycobactin, produced a vanadyl mycobactin complex which was not susceptible to enzymic reduction (unpublished work) in the same way that ferrimycobactin is known to be (McCready \& Ratledge, 1979). Thus, vanadate once complexed to mycobactin would not be susceptible to removal. Although the formation in situ of the vanadyl complex, like. that of the ferric complex, was unaffected by temperature, staining of the cells was still carried out at $4{ }^{\circ} \mathrm{C}$ to minimize lipid fluidity as well as any enzymic activity that might have affected the stability or migration of the complex. In addition to its good complexing ability with mycobactin, vanadate is more electron-dense than iron and can be readily seen by electron microscopy. Ammonium metavanadate also proved to be a good negative-stain for whole cells.

\section{Examination of whole cells of $M$. smegmatis using ammonium metavanadate as a mycobactin-specific stain}

Cells grown for $4 \mathrm{~d}$ in iron-sufficient or iron-deficient medium were incubated with $0.1 \%$ ammonium metavanadate at $4{ }^{\circ} \mathrm{C}$ (see Methods) and examined with the electron microscope. Grids were prepared in a similar manner to that used for conventional negative-staining techniques (Hayat, 1970, 1972). These iron-deficient cells had a mycobactin content of $4.8 \%$; the mycobactin content of the iron-sufficient cells, although not determined, would have been no more than $0.005 \%$ (Ratledge \& Marshall, 1972). Excess ammonium metavanadate was not removed so as to enable the outer peripheral layer of the cell envelope 


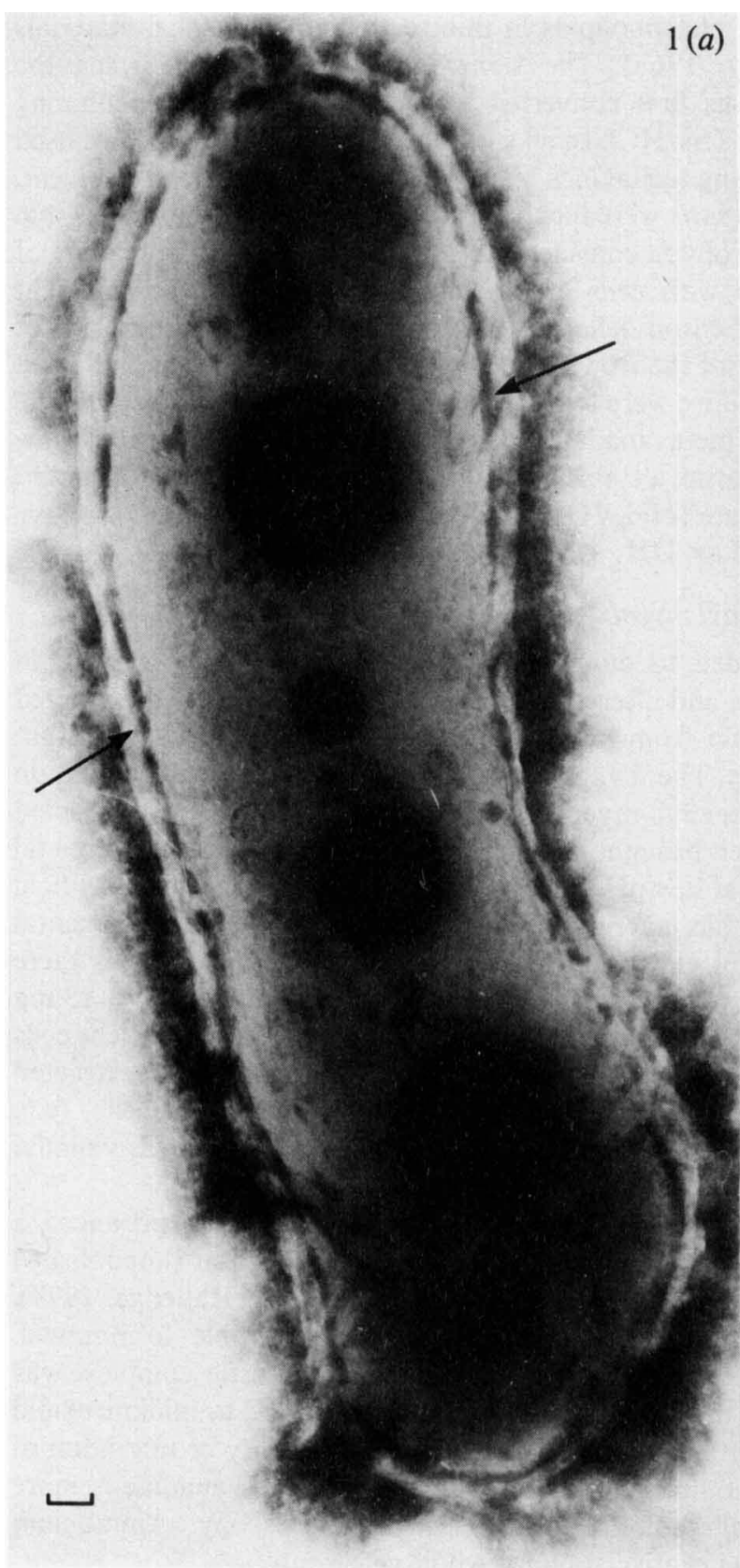

All the bar markers represent $0.1 \mu \mathrm{m}$

Fig. $1(a, b)$. Whole cells of $M$. smegmatis grown in iron-deficient medium and then incubated with $0.1 \%$ ammonium metavanadate for $10 \mathrm{~min}$ at $4{ }^{\circ} \mathrm{C}$ (see Methods). Arrows indicate the location of vanadyl mycobactin. The electron-dense circular bodies are probably polyphosphate granules.

Fig. 2. Whole cell of $M$. smegmatis grown in iron-sufficient medium and then incubated with ammonium metavanadate as in Fig. 1.
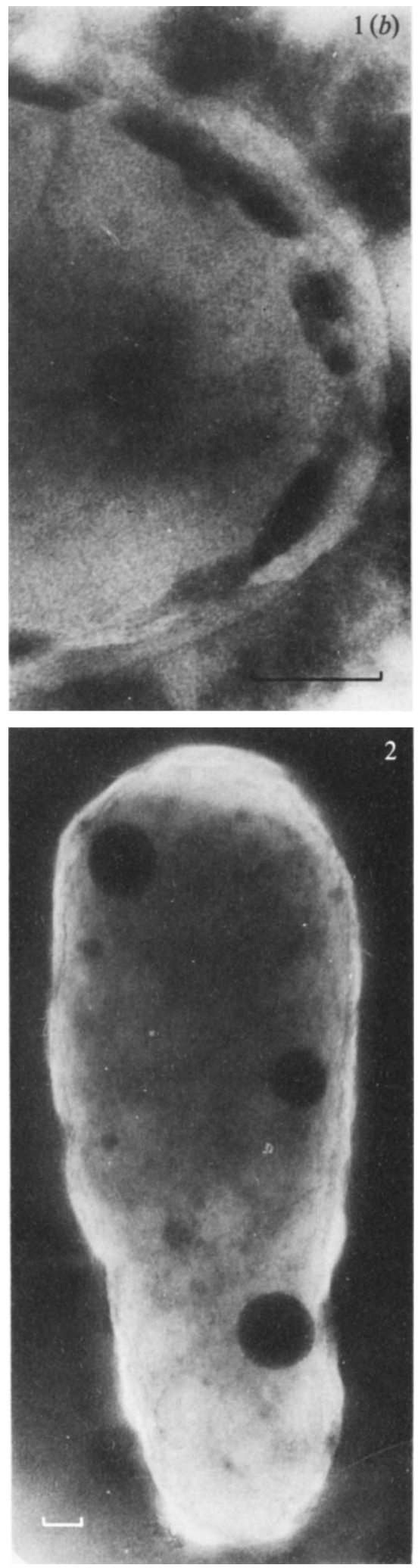


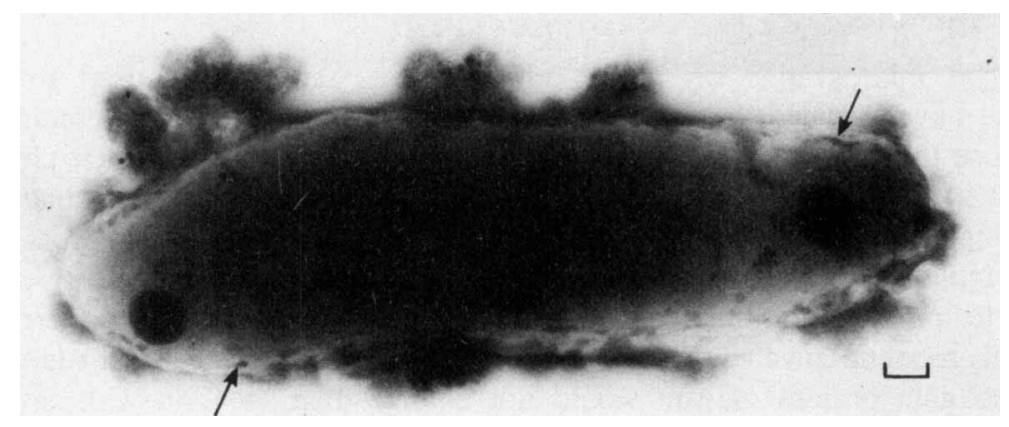

Fig. 3. Whole cell of $M$. smegmatis grown in iron-deficient medium and then incubated with $0.1 \%$ ammonium metavanadate for $30 \mathrm{~s}$ at $4{ }^{\circ} \mathrm{C}$. Arrows indicate the location of vanadyl mycobactin. The bar marker represents $0.1 \mu \mathrm{m}$.

to be contrasted. A large number of cells from both iron-deficient and iron-sufficient cultures were examined. In the former cells a distinct, positively stained (electron-dense) layer was seen within the cell envelope in the region of the cytoplasmic membrane (Fig. 1). This electron-dense layer was absent from cells grown in iron-sufficient medium (Fig. 2). If the excess ammonium metavanadate was washed from the cells before electron microscopy, the definition of the outer layers as seen in Fig. 1 was lost thus making it slightly more difficult to contrast the mycobactin layer.

Although mycobactin was clearly seen to be surrounding the mycobacterial cell in an apparently discrete but discontinuous inner layer of the outer envelope, it was not possible to equate this layer with the cytoplasmic membrane unequivocally due to lack of definition of the membrane, even at the highest magnification attainable (see Fig. $1 b$ ). In iron-sufficient cells exposed to vanadate (Fig. 2) there was a faint but continuous inner electron-dense layer at the expected position of the cytoplasmic membrane, corresponding to the position of the mycobactin in iron-deficient bacteria. The distance between this region and the outer surface of the cell was approximately $30 \mathrm{~nm}$, i.e. about the thickness of the cell wall noted by other workers (see Introduction).

The inner and strongly electron-dense layer in iron-deficient cells was identified as vanadyl mycobactin on the basis of the following observations. First, the vanadyl mycobactin complex could be extracted from the cells and identified as such (see above). Secondly, when iron-deficient cells (mycobactin content $4.5 \%$ ) were dehydrated in a graded series of ethanol/water mixtures about $95 \%$ of the total mycobactin was extracted; these cells, when gradually rehydrated and incubated with ammonium metavanadate as before, showed complete absence of the mycobactin layer and looked identical to iron-sufficient cells which had been similarly treated. Thus, vanadyl mycobactin is electron-dense and can be formed only in iron-deficient cells possessing mycobactin.

The formation of the vanadyl mycobactin complex within the cell was found to be time-dependent. Cells exposed to ammonium metavanadate showed slight staining in the mycobactin region after $30 \mathrm{~s}$ exposure (Fig. 3). However, even at the earliest times of sampling (30s-3 min) the staining was more or less completely around the cell. Only after longer periods of exposure $(6-20 \mathrm{~min})$ was a thickening of the mycobactin region seen, as depicted in Fig. 1. Apart from the staining of mycobactin and the heavy staining of polyphosphate granules (apparent in all micrographs), there appeared to be no other specific region which was selectively stained by the vanadate. The optimum length of time for exposure of the cells to metavanadate to visualize the mycobactin zone was about 8-10 min but was not critical; exposure for 20 min tended to damage the cells. Even after the longest exposure times, the mycobactin region was never seen to be a completely continuous layer and did not look any different from the micrographs shown in Fig. 1. 


\section{DISCUSSION}

The electron micrographs of whole cells of $M$. smegmatis exposed to ammonium metavanadate have revealed the location of mycobactin as a discrete, discontinuous region within, or close to, the cytoplasmic membrane. It does not form a zone stretching from the outermost layers of the envelope to the inside. Although the majority of mycobactin is present in the growing cell as an uncomplexed molecule, it is unlikely to change its location on becoming complexed to iron or to any other metal ion. Loading experiments were all carried out at $4{ }^{\circ} \mathrm{C}$ to minimize the fluidity of lipid components, and furthermore, ferrimycobactin and desferrimycobactin have equal affinities for a lipid/water interface (Ratledge \& Marshall, 1972) and so gain or loss of iron would not change their location with respect to any lipid/water boundary layer. The observed location of vanadyl mycobactin is therefore likely to be the location of the uncomplexed molecule. This is supported by electron micrographs taken at intervals from $30 \mathrm{~s}$ to $20 \mathrm{~min}$ in which the position of mycobactin did not appear to change.

The position of mycobactin appears to be close to or even coincident with the cytoplasmic membrane. It is unlikely, though, that all the mycobactin of an iron-deficient mycobacterium could be wholly accommodated within the cytoplasmic membrane in view of the large amount of it: mycobactin can represent up to $10 \%$ of the cell mass whereas the membrane itself represents only about $1 \%$ of the cell mass. By analogy with sterol accommodation in membranes, when once the ratio of sterol to phospholipid exceeds $50: 50(\mathrm{~mol} / \mathrm{mol})$ membranes become disrupted and lose the bilayer configuration (Ladbrooke et al., 1968; Lecuyer \& Dervichian, 1969), one could conclude that it would be impossible for the mycobactin to be accommodated beyond a similar concentration within the cytoplasmic membrane.

Further work is required to determine the exact location of mycobactin, which probably cannot be decided upon the basis of electron microscopy alone. It is possible that a small amount of mycobactin may be accommodated within the membrane, with the vast majority lying adjacent to it but not forming part of the membrane. In this way mycobactin would be able to act both as an ionophore for the uptake of iron across the membrane and as a store of iron. An alternative model is that no mycobactin occurs in the membrane and all of it is intercalated between the cytoplasmic membrane and the peptidoglycan backbone, which in mycobacteria abuts on to the cytoplasmic membrane without an intervening periplasmic space (Draper, 1982). In this model, mycobactin would be envisaged as functioning solely as a store of iron.

There are some difficulties with both models. In the first, problems of transfer of mycobactin - initially as the ferri complex and then as the desferri-molecule - between the bulk pool of mycobactin and the cytoplasmic membrane have to be considered if the transport of iron into the cytoplasm is to be achieved in a regulated manner. In the second, where mycobactin acts only as a store of iron, a mechanism for iron transport across the membrane must be proposed which would explain how iron is removed from mycobactin (though this is probably by an NADH-linked reductase; McCready \& Ratledge, 1979), transferred to an acceptor molecule and then transported across the membrane. Until more is known about the association of mycobactin with the lipids of the cytoplasmic membrane it is premature to speculate further as to how either or both of these models might operate. Suffice it to say that mycobactin occurs in discrete 'pockets' or regions of the cell envelope which are close to the cytoplasmic membrane making it possible for it to act either as a store of iron or as an ionophore or even to fulfil both these roles.

This work was supported by a grant-in-aid from The Wellcome Trust. We thank Dr M. J. Moore of this Department for helpful discussions. 


\section{REFERENCES}

Biava, C. G. \& Shelley, S. (1968). Extraction of tissue lipid components during processing for electron microscopy. Journal of Cell Biology 39, $15 \mathrm{a}$.

DRAPER, P. (1982). The anatomy of the mycobacteria. In The Biology of the Mycobacteria, vol. 1, pp. 9-52. Edited by C. Ratledge \& J. L. Stanford. London: Academic Press.

Hayat, M. A. (1970). Principles and Techniques of Electron Microscopy; Biological Applications, vol. 1. New York \& London: Van Nostrand Reinhold.

Hayat, M. A. (1972). Principles and Techniques of Electron Microscopy; Biological Applications, vol. 2. New York \& London: Van Nostrand Reinhold.

Ladbrooke, B. D., Williams, R. M. \& Chapman, D. (1968). Studies on lecithin-cholesterol-water interactions by differential scanning calorimetry and $\mathrm{X}$-ray diffraction. Biochimica et biophysica acta 150, 333-340.

Lecuyer, H. \& Dervichian, D. G. (1969). Structure and aqueous mixtures of lecithin and cholesterol. Journal of Molecular Biology 45, 39-57.

Lederer, E. (1971). The mycobacterial cell wall. Pure and Applied Chemistry 25, 135-165.

McCready, K. A. \& Ratledge, C. (1978). Amounts of iron, haem and related compounds in $\mathrm{Myco}^{-}$ bacterium smegmatis grown in various concentrations of iron. Biochemical Society Transactions 6 , 421-423.

McCready, K. A. \& Ratledge, C. (1979). Ferrimycobactin reductase activity from $\mathrm{Myco}$ bacterium smegmatis. Journal of General Microbiology 113. 67-72.

MinNikin, D. E. (1982). Lipids: complex lipids, their chemistry, biosynthesis and roles. In The Biology of the Mycobacteria, vol. 1, pp. 95-184. Edited by C. Ratledge \& J. L. Stanford. London: Academic Press.

Müller, G. \& Winkelmann, G. (1980). Arsenate causes an immediate loss of bound siderophores from cytoplasmic membranes of fungi. FEMS Microbiology Letters 9, 149-153.

Müller, G. \& WinkelmanN, G. (1981). Binding of siderophores to isolated plasma membranes of Neurospora crassa. FEMS Microbiology Letters 10 , $327-331$.

Ratledge, C. (1976). The physiology of the mycobacteria. Advances in Microbial Physiology 13, 115-244.

RatledGe, C. \& Hall, M. J. (1971). Influence of metal ions on the formation of mycobactin and salicylic acid in Mycobacterium smegmatis grown in static culture. Journal of Bacteriology 108, 312319.

Ratledge, C. \& Marshall, B. J. (1972). Iron transport in Mycobacterium smegmatis: the role of mycobactin. Biochimica et biophysica acta 279 , 58-74.

Ratledge, C., Macham, L. P., Brown, K. A. \& MARSHALL, B. J. (1974). Iron transport in Mycobacterium smegmatis: a restricted role for salicylic acid in the extracellular environment. Biochimica et biophysica acta 372, 39--51.

Ryter, A., Kellenberger, E., Birch-Andersen, A. \& MaAløE, A. (1958). Etude au microscope èlectronique de plasmas contenant de l'acide désoxyribonucléique. I. Les nucléotides des bactéries en croissance active. Zeitschrift für Naturforschung 13b, 597-605.

Silva, M. T., Santos Mota, J. M., Melo, J. V. C. \& Carvalho Guerra, F. (1971). Uranyl salts as fixatives for electron microscopy. Study of the membrane ultrastructure and phospholipid loss in bacilli. Biochimica et biophysica acta 233, 513-520.

SNOw, G. A. (1969). Metal complexes of mycobactin P and desferrisideramines. Biochemical Journal 15, 199-205.

SNow, G. A. (1970). Mycobactins: iron-chelating growth factors from mycobacteria. Bacteriological Reviews 34, 99-125. 